\title{
HUBUNGAN KEPATUHAN KONSUMSI KELASI BESI SETELAH TRANSFUSI DENGAN PERTUMBUHAN PADA ANAK THALASSEMIA USIA SEKOLAH DI RSU HARAPAN BUNDA JAKARTA TIMUR 2017
}

\author{
Dewi Fitriani ${ }^{1}$, Novi Nuranisa Indah ${ }^{2}$ \\ Stikes Widya Dharma Husada Tangerang \\ e-mail: dewifitriani@wdh.ac.id
}

\begin{abstract}
ABSTRAK
Thalassemia adalah kelainan genetic yang ditandai oleh penurunan atau tidak adanya sintesis atau beberapa rantai polipeptida globin. Berdasarkan data dari World Health Organization (WHO )tahun 2013 memperkirakan $7 \%$ dari penduduk dunia mempunyai gen thalassemia. Prevalensi Penderita thalasemia diindonesia sekitar $6-$ 10\%. Di RSU Harapan Bunda Jakarta Timur anak thalasemia usia sekolah mencapai 50 orang. Pengobatan yang diberikan pada pasien thalassemia adalah transfusi dan kelasi besi. Tujuan pemberian kelasi besi ialah untuk mencapai keseimbangan zat besi dan mencegah penimbunan zat besi pada berbagai organ tubuh akibat transfusi, yang dapat menghambat pertumbuhan pada anak thalassemia. Tujuan: Tujuan penelitian ini adalah Untuk mengidentifikasi hubungan kepatuhan konsumsi kelasi besi setelah transfusi dengan pertumbuhan pada anak thalassemia usia sekolah di RSU Harapan Bunda Jakarta Timur Tahun 2017. Metode: Metode penelitian ini adalah Cross Sectional dan metode sampling yang digunakan non-probability sampling yaitu total sampling. sampel dalam penelitian ini berjumlah 50 orang yaitu anak thalassemia usia sekolah. Hasil: Hasil Penelitian ini dengan menggunakan uji Chi-Square didapatkan sebanyak sebagian besar responden yang tidak patuh mengkonsumsi kelasi besi setelah transfusi dan pertumbuhan tidak normal sebanyak 26 orang (52\%), dan sebagian responden yang patuh mengkonsumsi kelasi besi setelah transfusi dan pertumbuhan normal sebanyak 24 orang (48\%), Dengan hasil nilai p-value 0.000. Kesimpulan: Maka dapat disimpulkan bahwa ada hubungan yang signifikan antara kepatuhan konsumsi kelasi besi setelah transfusi dengan pertumbuhan pada anak thalassemia. Saran: Saran dari penelitian ini diharapkan pada penelitian selanjutnya dapat membahas factor lainnya yang dapat mempengaruhi kepatuhan konsumsi kelasi besi setelah transfusi dengan pertumbuhan anak thalasemia.
\end{abstract}

Kata kunci : Thalasemia, Kepatuhan Konsumsi kelasi besi setelah transfusi, dan Pertumbuhan

\begin{abstract}
ABSTRAK
Thalassemia is a genetic disorder characterized by a decrease or absence of synthesis or some globin polypeptide chain. Based on data from the World Health Organization (WHO) in 2013 estimated that $7 \%$ of the world's population has thalassemia genes. Prevalence Patients with thalassemia in Indonesia about 6 - 10\%. At RSU Harapan Bunda Jakarta Timur school-age thalassemia children reach 50 people. Treatments given to thalassemia patients are transfusions and iron chelations. The objective of iron sailing is to achieve iron balance and prevent the accumulation of iron in various organs due to transfusion, which can inhibit growth in children with thalassemia. Purpose: The purpose of this research is to identify the relation of iron sail adherence after transfusion with growth in child of school age thalassemia at Harapan Bunda Hospital of East Jakarta Year 2017. Methods: This research method is Cross Sectional and sampling method used non-probability sampling that is total sampling. The sample in this study amounted to 50 people namely school-age thalassemia children. Result: The results of this study using Chi-Square test found that most of the respondents who did not adhere to consuming iron chelation after transfusion and abnormal growth as many as 26 people (52\%), and some respondents who dutifully consume iron sail after transfusion and normal growth of 24 people (48\%), with the result of p-value 0.000. Analize: So It can be concluded that there is a significant relationship between
\end{abstract}


adherence of iron chelation adherence after transfusion with growth in child thalassemia. Discussion: from this research is expected in subsequent research can discuss other factors that can influence compliance of iron chelation after transfusion with growth of child thalasemia.

Keywords : Thalassemia, Compliance Consumption of iron sail after transfusion, and Growth

\section{Pendahuluan}

Prevalensi penderita thalassemia Menurut WHO dalam Pohan dkk tahun 2013, 7\% dari penduduk dunia mempunyai gen thalassemia, dimana angka kejadian tertinggi sampai dengan $40 \%$ kasusnya adalah di Asia dan angka penderita di Indonesia 6-10\%.

Hasil Riset Kesehatan Dasar tahun 2007 menunjukkan prevalensi nasional thalassemia adalah $0,1 \%$. Semua terdapat di 8 propinsi yang menunjukkan prevalensi thalasemia lebih tinggi dari prevalensi nasional. Dari 8 propinsi tersebut diantaranya adalah Aceh dengan prevalensi $13,4 \%$, Jakarta dengan 12,3\%, Sumatera Selatan yang prevalensinya 5,4\%, Gorontalo dengan persentase 3,1\%, dan Kepulauan Riau 3\%. dan data Depkes pada tahun 2016 menyebutkan bahwa DKI Jakarta menduduki angka ke-2 tertinggi sebesar 12,3\%. Berdasarkan studi pendahuluan di RSU Harapan Bunda Jakarta Timur dengan presentase penderita thalassemia usia sekolah pada tahun 2015 sekitar 42\% sedangkan pada tahun 2016 penderita thalassemia usia sekolah mengalami peningkatan sekitar $2 \%$ saat ini menjadi $44 \%$.
Hasil studi pendahuluan didapatkan dari RSU Harapan Bunda Jakarta Timur, Jumlah penderita thalassemia pada tahun 2015 sebanyak 80 orang dan pada tahun 2016 jumlah pasien thalassemia sebanyak 88 orang.

Berdasarkan latar belakang diatas peneliti tertarik untuk mengetahui adakah "Hubungan Konsumsi Kelasi Besi Setelah Transfusi dengan Pertumbuhan Pada Anak Thalassemia usia sekolah di RSU Harapan Bunda Jakarta Timur".

\section{Desain Penelitian}

Desain penelitian ini adalah penelitian deskriptif analitik dengan pendekatan Cross Sectional. Untuk mengetahui apakah ada hubungan kepatuhan konsumsi kelasi besi setelah transfusi di RSU Harapan Bunda Jakarta Timur.

\section{Populasi dan sampel}

Populasi dalam penelitian ini adalah 50 anak Thalassemia di Rumah Sakit Harapan Bunda Jakarta Timur. Dengan menggunakan metode nonprobability dengan tehnik pengambilan sampel total sampling yaitu sebanyak 50 orang. 


\section{Analisa Data}

Analisis Univariate dalam penelitian ini untuk mengetahui distribusi frekuensi pada karakteristik responden (usia, jenis kelamin, lamanya positif thalassemia, dan IMT). Terdiri dari dua variabel yaitu kepatuhan konsumsi kelasi besi setelah transfusi sebagai variabel independent dan pertumbuhan pada anak thalassemia usia sekolah sebagai variabel dependent.

Analisis bivariate pada penelitian ini dilakukan untuk mengetahui hubungan antara kepatuhan konsumsi kelasi besi setelah transfusi dengan pertumbuhan pada anak thalassemia usia sekolah menggunakan uji chi square.

\section{Hasil Penelitian}

Hasil penelitian yang telah dilaksanakan oleh peneliti pada bulan Februari - Juni 2017 dan pengambilan data dilaksanakan di Ruang Thalassemia RSU Harapan Bunda Jakarta Timur. Adapun tujuan penelitian ini adalah untuk mengetahui "Hubungan Kepatuhan Konsumsi Kelasi Besi Setelah Transfusi pada Anak Thalassemia Usia Sekolah di RSU Harapan Bunda Jakarta Timur". Dengan jumlah responden 50 orang.

\section{a. Usia}

Tabel 5.1. Karakteristik Distribusi Frekuensi dan Persentasi Berdasarkan Usia Responden $(\mathrm{n}=50)$

\begin{tabular}{ccccc}
\hline Usia (tahun) & n & $\%$ & $\begin{array}{c}\text { Mean } \\
\text { Min- } \\
\text { max }\end{array}$ \\
\hline $6-9$ Thn & 19 & 38 & 10 & $6-12$ \\
$10-12$ Tthn & 31 & 62 & & \\
\hline
\end{tabular}

Berdasarkan tabel 5.1 menunjukkan bahwa lebih dari setengahnya berusia $10-12$ Tahun 31 orang (62\%) dan hampir setengahnya berusia 6 - 9 tahun 19 orang $(38 \%)$ didapatkan usia termuda 6 tahun dan tertua 12 tahun dengan nilai rata - rata usia 10 tahun.

\section{b. Jenis Kelamin}

Tabel 5.2. Karakteristik Distribusi Frekuensi dan Persentasi Berdasarkan Jenis Kelamin Responden $(\mathrm{n}=50)$

\begin{tabular}{ccc}
\hline Jenis Kelamin & n & \% \\
\hline Laki - Laki & 24 & 48 \\
Perampuan & 26 & 52 \\
\hline
\end{tabular}

Berdasarkan tabel 5.2 menunjukkan bahwa karakteristik berdasarkan jenis kelamin lebih dari setengahnya berjenis kelamin perempuan 26 orang (52\%) dan hampir setengahnya laki - laki 24 orang (48\%).

\section{c. Terdiagnosis Thalassemia}

Tabel 5.3. Karakteristik Distribusi Frekuensi dan Persentasi Berdasarkan Terdiagnosis Thalasemia Responden $(\mathrm{n}=50)$

\begin{tabular}{ccc}
\hline $\begin{array}{c}\text { Terdiagnosis } \\
\text { Thalasemia }\end{array}$ & $\mathbf{n}$ & $\boldsymbol{\%}$ \\
\hline$\leq 5$ tahun & 27 & 54 \\
$>5$ tahun & 23 & 46 \\
\hline
\end{tabular}


Berdasarkan tabel 5.3 menunjukkan bahwa lebih dari setengahnya Terdiagnosis Thalassemia $\leq 5$ tahun 27 orang (54\%), dan hampir setengahnya Terdiagnosis Thalassemia $>5$ tahun 23 orang (46\%).

\section{d. Berat Badan}

Tabel 5.4. Karakteristik Distribusi Frekuensi dan Persentasi Berdasarkan Berat Badan Responden $(\mathrm{n}=50)$

\begin{tabular}{ccc}
\hline Berat Badan (kg) & $\mathbf{N}$ & \% \\
\hline $12-25 \mathrm{Kg}$ & 24 & 48 \\
$26-42 \mathrm{Kg}$ & 26 & 52 \\
\hline
\end{tabular}

Berdasarkan tabel 5.4 menunjukkan bahwa berat badan $(\mathrm{kg})$ pada anak thalassemia usia sekolah lebih dari setengahnya memiliki berat badan $26-42 \mathrm{Kg}$ dengan jumlah 26 orang (52\%) dan hampir setengahnya memiliki berat badan $12-25 \mathrm{Kg}$ dengan jumlah 24 orang (48\%).

\section{e. Tinggi Badan}

Tabel 5.5. Karakteristik Distribusi Frekuensi dan Persentasi Berdasarkan Tinggi Badan Responden ( $\mathrm{n}=50$ )

\begin{tabular}{ccc}
\hline $\begin{array}{c}\text { Tinggi Badan } \\
(\mathbf{c m})\end{array}$ & $\mathbf{n}$ & $\boldsymbol{\%}$ \\
\hline $90-120 \mathrm{~cm}$ & 16 & 32 \\
$121-140 \mathrm{~cm}$ & 34 & 68 \\
\hline
\end{tabular}

Berdasarkan tabel 5.5 menunjukkan bahwa tinggi badan $(\mathrm{cm})$ anak thalassemia usia sekolah lebih dari setengahnya memiliki tinggi badan 121 - $140 \mathrm{~cm}$ dengan jumlah responden 34 orang $(68 \%)$ dan hampir setengahnya memiliki tinggi badan 90 $120 \mathrm{~cm}$ dengan jumlah responden 16 orang $(32 \%)$.

\section{f. Indeks Massa Tubuh}

Tabel 5.6. Karakteristik Distribusi Frekuensi dan Persentasi Berdasarkan Indeks Massa Tubuh Responden $(\mathrm{n}=50)$

\begin{tabular}{ccc}
\hline $\begin{array}{c}\text { Indeks Massa } \\
\text { Tubuh (IMT) }\end{array}$ & $\mathbf{n}$ & $\boldsymbol{\%}$ \\
\hline$\leq 18,5$ & 32 & 64 \\
$>18,5$ & 18 & 36 \\
\hline
\end{tabular}

Berdasarkan tabel 5.6 menunjukkan bahwa Indeks Massa Tubuh (IMT) anak thalassemia usia sekolah lebih dari setengahnya memiliki nilai $\mathrm{IMT} \leq 18,5$ dengan jumlah responden 32 orang (64\%) dan hampir setengahnya memiliki nilai IMT > 18,5 dengan jumlah 18 orang (36\%).

\section{g. Kepatuhan Konsumsi Kelasi Besi Setelah Transfusi}

Tabel 5.7. Karakteristik Distribusi Frekuensi dan Persentasi Berdasarkan Kepatuhan Konsumsi Kelasi Besi Setelah Transfusi Responden ( $\mathrm{n}=50$ )

\begin{tabular}{ccc}
\hline $\begin{array}{c}\text { Kepatuhan } \\
\text { Konsumsi Kelasi } \\
\text { Besi }\end{array}$ & N & \% \\
\hline Patuh & 24 & 48 \\
Tidak Patuh & 26 & 52 \\
\hline
\end{tabular}

Berdasarkan tabel 5.7 menunjukkan bahwa tingkat kepatuhan mengkonsumsi kelasi besi setelah transfusi lebih dari setengahnya tidak patuh dengan jumlah responden 26 orang (52\%) dan hampir setengahnya patuh dengan jumlah responden 24 orang (48\%). 
h. Persentasi Pertumbuhan

Tabel 5.8. Karakteristik Distribusi

Frekuensi dan Responden ( $\mathrm{n}=50$ )

\begin{tabular}{ccc}
\hline Pertumbuhan & N & \% \\
\hline Pertumbuhan Normal & 18 & 36 \\
Pertumbuhan Tidak & 32 & 64 \\
Normal & & \\
\hline
\end{tabular}

Berdasarkan tabel 5.8 menunjukkan bahwa pertumbuhan pada anak thalassemia usia sekolah lebih dari disetengahnya memiliki pertumbuhan tidak normal dengan jumlah responden 32 orang $(64 \%)$ dan hampir setengahnya memiliki pertumbuhan normal dengan jumlah responden 18 orang (36\%).

\section{i. Hubungan Kepatuhan Konsumsi Kelasi Besi Setelah Transfusi dengan Pertumbuhan}

Tabel 5.9 . Hubungan Kepatuhan Konsumsi Kelasi Besi Setelah Transfusi dengan Pertumbuhan Pada Anak Thalassemia Usia Sekolah

\begin{tabular}{ccccc}
\hline $\begin{array}{c}\text { Tingkat } \\
\text { Kepatuhan }\end{array}$ & \multicolumn{2}{c}{ Pertumbuhan } & Total & $\begin{array}{c}\text { P } \\
\text { Value }\end{array}$ \\
\cline { 2 - 3 } & Normal & $\begin{array}{c}\text { Tidak } \\
\text { Normal }\end{array}$ & & \\
\hline Patuh & 17 & 7 & 24 & 0.000 \\
& $(34 \%)$ & $(14 \%)$ & $(48 \%)$ & \\
Tidak & 1 & 25 & 26 & \\
Patuh & $(1 \%)$ & $(50 \%)$ & $(52 \%)$ & \\
\hline
\end{tabular}

Berdasarkan tabel 5.9 Hasil analisis diperoleh bahwa hampir setengahnya dengan tingkat kepatuhan yaitu patuh mengkonsumsi kelasi besi setelah transfusi 24 orang (48\%) dengan hampir setengahnya memiliki pertumbuhan normal sebanyak 17 orang (34\%) dan sisanya sebagian kecil memiliki pertumbuhan tidak normal sebanyak 7 orang (14\%), sedangkan lebih dari setengahnya tidak patuh mengkonsumsi kelasi besi setelah transfusi sebanyak 26 orang (52\%) dan hampir tidak ada responden yang memiliki pertumbuhan normal sebanyak 1 orang (2\%) dan sisanya setengah responden memiliki pertumbuhan tidak normal sebanyak 25 orang (50\%).

Hasil uji statistic diperoleh nilai p-value 0,000 dengan nilai $\alpha=0,05$, maka $p$-value $<$ nilai $\alpha$. Maka dengan demikian dapat disimpulkan bahwa Ha diterima artinya ada hubungan yang signifikan antara kepatuhan dalam mengkonsumsi kelasi besi setelah transfusi dengan pertumbuhan pada anak thalassemia di RSU Harapan Bunda Jakarta Timur.

Dari hasil uji statistic juga didapatkan nilai $X^{2}$ test yaitu 67,505 dan nilai Odds Ratio (OR) sebesar 60,714 yang berarti responden dengan tingkat kepatuhan konsumsi kelasi besi setelah transfusi 60 kali memiliki pertumbuhan yang normal dibandingkan dengan responden yang tidak patuh mengkonsumsi kelasi besi setelah transfusi.

\section{PEMBAHASAN}

a. Kepatuhan Konsumsi Kelasi Besi Setelah Transfusi 
Hasil analisis univariate mengenai kepatuhan konsumsi kelasi besi setelah transfusi menunjukan bahwa dari 50 responden memiliki tingkat kepatuhan tidak patuh sebanyak 52,0\%. Hal ini menunjukkan masih minimnya tingkat kepatuhan konsumsi kelasi besi setelah transfusi pada anak thalassemia.

Keadaan tersebut dapat dikarnakan oleh beberapa factor yakni diantaranya kurangnya pemahaman tentang intruksi, kualitas intruksi antara tenaga medis dengan pasien, dukungan lingkungan dan keluarga, keyakinan dan sikap (Notoatmodjo, 2010 dalam Agustina 2014).

Hasil penelitian yang dilakukan oleh Rizkia, Fanina pada tahun 2016 dengan hasil tingkat kepatuhan minum obat kelasi besi hampir seluruh responden tidak patuh sebesar $80,0 \%$. Seperti yang diketahui bahwa tujuan kelasi besi yaitu untuk mengurangi toksisitas simpanan besi dalam jaringan, mencegah kelebihan besi dan keuntungan lain adalah memindahkan besi dari membrane sel darah merah.

Pendapat dari Ratnasari, tahun 2012 dalam sulistiyanti tahun 2015 kepatuhan dapat didefinisikan sebagai suatu perilaku manusia yang taat terhadap aturan, perintah, prosedur, dan disiplin. Dan diperkenalkannya kelasi besi yang dapat mengeluarkan kelebihan besi dari dalam tubuh telah mengubah harapan hidup pasien thalassemia (Priyantiningsih, 2010).

Pada hasil analisis diatas menunjukkan bahwa masih banyak anak thalassemia yang tidak mematuhi konsumsi kelasi besi setelah transfusi yang dikarenakan oleh beberapa factor. Padahal pentingnya tingkat kepatuhan dalam mengkonsumsi kelasi besi setelah transfusi pada anak thalassemia dikarnakan sesuai dengan fungsi dan perannya kelasi besi yang baik untuk mengurangi komplikasi penyakit seperti menurunkan penimbunan zat besi didalam tubuh anak thalassemia.

\section{b. Pertumbuhan Anak Thalasemia Usia Sekolah}

Berdasarkan hasil analisis Univariate mengenai pertumbuhan pada anak thalassemia usia sekolah penelitian ini menunjukkan bahwa $64,0 \%$ memiliki pertumbuhan tidak normal. Artinya sebagian besar responden memiliki pertumbuhan tidak normal, salah satu masalah penting yang dapat terjadi pada penderita thalassemia mayor adalah hambatan pertumbuhan. Gangguan pertumbuhan tersebut dapat terjadi dikarenakan pemberian transfusi yang tidak benar, deposit hemosiderosis pada organorgan yang berperan dalam pertumbuhan, 
atau karena tidak mendapat zat pengikat besi yang baik.

Menurut Bulan, Sandra, 2009 Gangguan pertumbuhan pada penderita thalassemia beta mayor yang terjadi pada anak usia dibawah 10 tahun berhubungan dengan hiperaktif sumsum tulang, pemberian transfusi yang sedikit atau yang tidak pernah mendapat transfusi dan pasien yang mengalami hipersplenisme.

Penelitian yang dilakukan oleh Alfianti pada tahun 2016 bahwa penelian ini menemukan adanya masalah pertumbuhan pada anak thalassemia disebabkan oleh status nutrisi, didapatkan hasil sebagian besar responden mengalami resiko tinggi malnutrisi sebanyak 22 orang $(55,0 \%)$.

Hasil analisis menunjukkan bahwa gangguan pertumbuhan dapat terjadi dikarenakan transfusi berlebih yang dapat menyebabkan penimbunan zat besi didalam tubuh. maka dari itu kepatuhan konsumsi kelasi besi harus sangat diperhatikan. Selain itu, hal yang juga perlu diperhatikan khusus ialah kebutuhan nutrisi pada anak thalassemia. Mengingat bahwa nutrisi juga sangat berperan penting dalam mengoptimalkan kinerja pada seluruh organ yang salah satunya ialah organ pertumbuhan.

\section{c. Hubungan Kepatuhan Konsumsi}

Kelasi Besi Setelah Transfusi dengan Pertumbuhan Pada Anak

\section{Thalassemia Usia Sekolah}

Berdasarkan hasil analisis bivariate menggunakan uji chi square mengenai hubungan kepatuhan konsumsi kelasi besi setelah transfusi dengan pertumbuhan anak thalassemia usia sekolah di RSU Harapan Bunda Jakarta Timur menunjukkan bahwa dari 50 orang responden dengan tingkat kepatuhan yaitu sebagian besar responden tidak patuh mengkonsumsi kelasi besi setelah transfusi dan pertumbuhan tidak normal sebanyak 26 orang (52\%). Hal ini dikarenakan minimnya tingkat kepatuhan konsumsi kelasi besi setelah transfusi yang mengakibatkan pertumbuhan tidak normal pada anak thalassemia.

Hasil analisis secara statistic menunjukkan bahwa nilai uji chi square didapatkan nilai $\mathrm{p}$ - value $0,000<0,05$ artinya Ha diterima. Dari analisis Maka dapat disimpulkan adanya hubungan yang signifikan antara kepatuhan dalam mengkonsumsi kelasi besi setelah transfusi dengan pertumbuhan pada anak thalassemia di RSU Harapan Bunda Jakarta Timur.

Hasil penelitian ini sejalan dengan hasil penelitian yang dilakukan oleh Safitri dan Rosnia pada tahun 2016 bahwa anak 
thalassemia yang patuh mengkonsumsi kelasi besi mempunyai pertumbuhan yang normal. Dengan hasil uji statistik menggunakan uji Chi Square diperoleh nilai $p$ value $=0,035<\alpha=0,05$ maka Ha gagal ditolak, sehingga dapat disimpulkan bahwa terdapat hubungan yang signifikan antara kepatuhan mengkonsumsi kelasi besi dengan pertumbuhan anak dengan thalasemia.

Menurut Made dan Arimbawa pada tahun 2011 Pengobatan terkini pada pasien thalassemia termasuk pemberian transfusi darah untuk mempertahankan $\mathrm{Hb}$ pada kadar yang dapat diterima dan kelasi untuk membuang kelebihan zat besi akibat pemberian beberapa transfusi.

Berdasarkan hal tersebut diatas, maka peneliti dapat menarik kesimpulan bahwa semakin tinggi tingkat kepatuhan anak thalassemia dalam mengkonsumsi kelasi besi setelah transfusi maka semakin tinggi pula anak thalassemia yang memiliki pertumbuhan normal, dikarenakan sesuai ilustrasi diatas bahwa obat kelasi besi sangat mempengaruhi system organ pertumbuhan.

\section{KESIMPULAN}

1. Diketahui tingkat kepatuhan konsumsi kelasi besi setelah transfusi pada anak thalassemia usia sekolah di RSU
Harapan Bunda Jakarta Timur, sebagian besar responden tidak patuh dengan jumlah responden 26 orang $(52 \%)$.

2. Diketahui tingkat pertumbuhan pada anak thalassemia usia sekolah di RSU Harapan Bunda Jakarta Timur, sebagian besar responden memiliki pertumbuhan tidak normal dengan jumlah responden 32 orang (64\%).

3. Ada hubungan yang signifikan antara kepatuhan konsumsi kelasi besi setelah transfusi dengan pertumbuhan pada anak thalassemia usia sekolah di RSU Harapan Bunda Jakarta Timur. Uji statistic Chi square, dengan probabilitas (p) $0.000<0,05$.

\section{Referensi}

Abdussalam, Reza dkk. 2016. "Perbedaan Kadar SGOT, SGPT dan GAMMA GT pada Pasien Talasemia Beta Mayor dengan Kelasi Besi Deferasiroks dan Deferipron" Diunduh pada tanggal 03 maret 2017

Agustina, Riya . 2014 ."Skripsi Hubungan Kepatuhan dengan Diet pada Pasien Diabetes Mellitus di Rumah Sakit Umum Kota Tangerang Selatan”.

Alfianti, Dera, Mariyam. 2016. "Prediksi Risiko Malnutrisi Berdasarkan Nutritional Risk Score (NRS) pada Anak Thalasemia di Kota

Semarang”. Diunduh pada tanggal 03 maret 2017

Amelia, Mercy, dkk."Hubungan Kadar Feritin Dan Ion Kalsium Serum Pada Penyandang Thalassemia Mayor Anak Yang Mendapat 
Transfusi Berulang" Sari Pediatri, Vol. 16, No. 1, Juni 2014 diunduh pada tanggal 03 maret 2017

Andriastuti, Murti dkk. "Kebutuhan Transfusi Darah Pasca-Splenektomi pada Thalassemia Mayor". Sari Pediatri, Vol. 13, No. 4, Desember 2011

https://saripediatri.org/index.php/sari -pediatri/article/download/442/373

diunduh pada tanggal 03 maret 2017

Asopari, Asep Aziz. 2014.“Hubungan Kadar Matriks Metaloproteinase-2 Serum dan Skor Aspartate To Platelet Ratio Index untuk Menilai Fibrosis Hati antara Penyandang Thalassemia yang Mendapat Terapi Kelasi Besi Deferoksamin dan Deferipron". Diunduh pada tanggal 03 maret 2017

Bulan, Sandra. 2009.'Tesis Faktor - Faktor Yang Berhubungan Dengan Kualitas Hidup Anak Thalasemia Beta Mayor". Diunduh pada tanggal 02 April 2017

Gatot, Djajadiman. 2007. "Pendekatan Mutakhir Kelasi Besi pada Thalassemia". Diperoleh pada tanggal 10 november 2016. // saripediatri.idai.or.id/pdfile/8-4-

2s.pdf diunduh pada tanggal 03 maret 2017

Hasan, Muhammad. 2014. "Interpretasi Data”; Jakarta

Hasnoto, Sutanto Priyo. 2011. "Basic Data Analysis for Health Research Training Analisa Dta Kesehatan. Fakultas Kesehatan Masyarakat Universitas Indonesia.

Ilmi, Sulsila dkk. 2014. "Hubungan Jenis Kelamin dan Domisili dengan Pertumbuhan Pada Anak Dengan
Thalasemia" Diunduh pada tanggal 03 maret 2017

Jacob, Annamma dkk. 2014."Buku Ajar Clinical Nursing Procedures Jilid Satu Ed.2". Tangerang Selatan : BINARUPA AKSARA Publisher

Jaya, Indra Kusuma dkk. "Gambaran Usia Tulang pada Pasien Talasemia dengan

Perawakan Pendek di Bagian Ilmu Kesehatan Anak RSUP Dr. Moh Hoesin Palembang”. Jurnal Kedokteran dan Kesehatan, Volume 2, NO. 2, April 2015: 217-222 // ejournal.unsri.ac.id/index.php/jkk/ar ticle/view/2560 diunduh pada tanggal 06 maret 2017

Karlina, Novvi dkk, 2014." asuhan Kebidanan Kegawatdaruratan Maternal \& Neonatal". Bogor : In Media

Kiswari, Rukman. 2014. "Hematologi \& Transfusi”. Jakarta : Erlangga

Kusyati, Eni dkk. 2012."Keterampilan \& Prosedur laboratorium Keperawatan dasar Ed.2". Jakarta : EGC

Kyle, Terri, 2014. 'Buku Ajar Keperawatan Pediatri”, Ed. 2. Jakarta : EGC

Made, Arimbawa dkk. 2011. "Profil Pertumbuhan, Hemoglobin Pretransfusi, Kadar Feritin, dan Usia Tulang Anak pada Thalassemia Mayor" Vol. 13, No. 4, Desember 2011 // https://saripediatri.org/index.php/sari pediatri/article/download/428/360 diunduh pada tanggal 05 april 2017

Maryanti, Dwi, Dkk. 2011."Buku Ajar Neonatus, Bayi dan Balita". Jakarta : TIM. 
Masruroh, Siti. 2014. "Keperawatan Pediatri”. Yogyakarta : Imperium.

Menurut Ratih P, Dewi, dkk. 2011. "Pengaruh Deferasirox Terhadap Kadar T4dan TSH pada B Thalasemia mayor dengan kadar Ferritin Tinggi”. Sari Pediatri, Vol. 12, No. 6

Mercy, Amelia dkk. 2014. "Hubungan Kadar Feritin dan Ion Kalsium Serum pada Penyandang Thalassemia Mayor Anak yang Mendapat Transfusi Berulang". Vol. 16, No. 1, Juni 2014 // https://saripediatri.org/index.php/sari -pediatri/article/download/168/158 diunduh pada tanggal 11 maret 2017

Mulyani dkk. "Reaksi Psikososial Terhadap Penyakit di Kalangan Anak Penderita Talasemia Mayor di Kota Bandung”. Informasi Vol. 16 No. 03 Tahun 2015 // puslit.kemsos.go.id/download/119 diunduh pada tanggal 19 maret 2017

Muttaqin, Arif. 2012. “Buku Ajar Asuhan Keperawatan dengan Gangguan Sistem Kardiovaskuler dan Hematologi”. Jakarta : Salemba Medika.

Notoatmodjo, soekidjo. 2012. "Metodologi Penelitian Kesehatan”. Jakarta : Rineka Cipta.

Notoatmodjo, soekidjo. 2012. "Promosi Kesehatan dan perilaku kesehatan”. Jakarta : rineka cipta.

Nursalam. 2016. "Metodologi Penelitian Ilmu Keperawatan Pendekatan Praktis Ed: 4".Jakarta : Salemba Medika

Pohan, Anggi dkk. "Efek Kelasi Ekstrak Etanol Daun Mangifera foetida pada Feritin Serum Penderita Talasemia di RS Cipto Mangunkusumo, Tahun 2012" Vol. 1, No. 1, April 2013 //
journal.ui.ac.id/index.php/eJKI/artic le/view/1595/1342 diunduh pada tanggal 13 maret 2017

Priyantiningsih, Dewi Ratih. "Pengaruh Deferasirox Terhadap Kadar T4 dan TSH pada Penderita B-Thalasemia dengan Ferritin yang Tinggi" 2010 // https://saripediatri.org/index.php/sari -pediatri/search?subject=thalassemia diunduh pada tanggal 2 febuary 2017

Rachmat, Ivan, dkk. "Hubungan Jumlah Darah Transfusi, Pemberian Deferoksamin, dan Status Gizi dengan Kadar Seng Plasma pada Penderita Thalasemia Mayor Anak" 2008. Diunduh pada 22 januari 2017

Rahman, R Topan A. 2015. "Analisis Statistik Penelitian Kesehatan". Bogor : IN MEDIA

Rahmawati, Ita."Perbedaan Pertumbuhan Anak Umur 5-6 Tahun Antara Jenis Kelamin Laki-Laki Dengan Jenis Kelamin Perempuan Berdasarkan Berat Badan Dan Tinggi Badandi Tk Aisyiyah purwogondo". Volume 3 No. 1 Maret 2012

jurnal.akbidalhikmah.ac.id/index.php /jkb/article/download/82/80 diunduh pada tanggal 09 April 2017

Ratih P, Dewi. 2011."Pengaruh Deferasirox Terhadap Kadar T4 dan TSH dengan B-Thalasemia Mayor dengan Kadar Ferritin Tinggi"// eprints.undip.ac.id/28996/1/Dewi_R atih_Priyantiningish_Tesis.pdf diunduh pada tanggal 03 April 2017

Redaksi ISO Indonesia. 2015-2016. “ISO Informasi Spesialite Obat Indonesia Volume 49 ISSN 0854 - 4492". Jakarta : PT. ISFI Penerbitan

Rejeki, Dwi Sarwani Sri. "Model Prediksi Kebutuhan Darah untuk Penderita 
Talasemia Mayor". Kesmas, Jurnal Kesehatan Masyarakat Nasional Vol. 8, No. 7, Februari 2014 //download.portalgaruda.org/article. php?. diunduh pada tanggal 20 february 2017

Rizkia, Fanina. 2016. "Skripsi Hubungan Antara Kepatuhan Minum Obat Kelasi Besi dengan Pertumbuhan Linier Anak Penderita Thalasemia Beta Mayor di Sentral Thalasemia RSUD dr Zainoel Abidin Banda Aceh".// etd.unsyiah.ac.id/pdf.php?id Diunduh pada tanggal 07 April 2017

Rosifah, Diana. "Perbandingan Kadar NAcetyl-ß-DGlucosaminidase Urin pada Thalassemia $B$ Mayor Anak yang Mendapat Deferipron dan Deferasiroks". Sari Pediatri, Vol. 16, No. 3, Oktober 2014 // https://saripediatri.org/index.php/sari -pediatri/article/view/195 diunduh pada tanggal 23 february 2017

Safitri, Rosnia, dkk. 2016."Hubungan Kepatuhan Tranfusi Dan Konsumsi Kelasi Besi Terhadap Pertumbuhan Anak Dengan Thalasemia" JOM Vol 2 No 2, Oktober 2015 diunduh pada tanggal 04 maret 2017

Soetjiningsih . 2012 . "Tumbuh Kembang Anak”. Jakarta : EGC.

Sugiyono. 2015. "Statistika Untuk Penelitian". Bandung : Alfabet

Sulistiyanti, Anik. "Hubungan Tingkat Pengetahuan Ibu Hamil Tentang Anemia dengan Kepatuhan Konsumsi Tablet FE di Wilayah Kerja Puskesmas Masaran I Sragen" Volume 2 / Nomor 2 / November 2015

ejurnal.akbidcm.ac.id/index.php/mat ernity/article/view/32 diunduh pada tanggal 03 february 2017
Tim penulis poltekes kemenkes Maluku. 2011. "penuntun praktikum keterampilan kritis II mahasiswa D-3 keperawatan". Jakarta : Salemba medika

Wijaya, Andra Saferi dkk. 2013. "Keperawatan Medikal Bedah 2". Yogyakarta : Nuha Medika

Wijayaningsih, Kartika Sari. 2013. "Asuhan Keperawatan Anak". Jakarta : TIM. 